\title{
Nyere doktoravhandlinger i suicidologi
}

Anne Marie Berg disputerte for dr.polit.-graden 16. desember 2005: Work stress and health in Norwegian police: a nationwide study.

ISBN 82-8072-210-6

Politiyrket har på mange måter vært et myteomspunnet yrke. Påstander om blant annet høyt stressnivå, høyt alkoholforbruk og høye selvmordsrater har vært fremsatt, ofte uten tilfredsstillende dokumentasjon. I denne doktoravhandlingen har vi undersøkt arbeidsstress og helse i en landsomfattende tverrsnittsstudie blant 3272 polititjenestemenn. Det er til nå den største undersøkelsen i sitt slag som er utført. A vhandlingen omfatter seks vitenskapelige artikler om stress, alkoholbruk, hjelpsøking og selvmordsatferd i norsk politi.

Resultatene viser at det ikke nødvendigvis er de yrkesspesifikke faktorene som oppleves som mest stressende. Det viser seg heller at rutinepreget politiarbeid, overtid, tidsfrister o.l. ble opplevd som mest belastende. Liknende funn er gjort også i mange andre yrkesgrupper. Forekomsten av høyt al koholforbruk var lavere blant norsk politi enn blant politifolk i A ustralia, men på samme nivå som blant norske leger. Studien avkrefter dermed antakelsen om at alkoholforbruket i politiet er spesielt høyt.

Selv om den egenrapporterte helsen i politiet var god, var forekomsten av subjektive helseplager relativt høy. Fysiske og mentale helseplager ble hovedsakelig forbundet med det daglige jobbpresset og mangel på støtte fra overordnet. Respondentene kontaktet psykolog/psykiater sjeldent, selv når de rapporterte suicidale tanker.

En systematisk litteraturgjennomgang av selvmord i politiet kunne ikke dokumentere en høy selvmordsrate internasjonalt. D ata fra tverrsnittsstudien viste dessuten en lav egenrapportert forekomst av selvmordstanker og selvmordsplaner. M enn knyttet oftere alvorlige selvmordstanker til problemer $i$ arbeidet enn kvinner.

\author{
Kari Vevatne disputerte for \\ dr.polit.-graden 2. februar \\ 2006: Selvmordsforsøket - \\ søken mot livet. \\ ISBN 82-308-0103-7
}

A vhandlingen belyser hvordan det oppleves å leve videre etter et selvmordsforsøk. I N orge forsøker hvert år mer enn 5000 personer å ta sitt eget liv. A vhandlingen presenterer intervjuer med personer som har gjort et selvmordsforsøk, 21 personer føl ges gjennom de første ukene etter selvmordsforsøket. $\mathrm{H}$ ensikten med avhandlingen er å vinne ny kunnskap om tiden etter selvmordsforsøket. Denne kunnskapen vil brukes i utvikling av kvalitetsforbedrende tiltak for mennesker som har forsøkt å ta sitt eget liv slik at gode og langvarige oppfølgingstiltak kan gjennomføres for den enkelte. A vhandlingen drøfter også holdninger til - og reaksjoner på selvmordsforsøket i kulturhistorisk sammenheng og i lys av vår kulturelle samtid, hvor spesielt relasjoner tillegges betydning.

G jennom intervjuene framkommer beskrivelser av grunnleggende tristhet, opplevelser av skam og av indre smerte. Det oppleves vanskelig å ta aktiv del i livet, deltakerne beskriver seg som tilskuere til livet. For mange var selvmordsforsøket utløst av ønske om et annet liv og ikke om å avslutte livet. Livet endret seg derimot ikke etter selvmordsforsøket, livet fortoner seg på samme måte etter forsøket, som før forsøket. Deltakerne beskriver en lengsel etter nærhet til andre basert på gjensidige og likeverdige relasjoner.

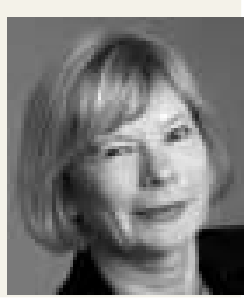

Siri Thoresen disputerte for dr.psychol.-graden 24. mars 2006: Suicide in peacekeepers: a study of risk factors for suicide in Norwegian veterans of international military operations.

Studien viser en moderat økt forekomst av selvmord blant norske FN / N AT O -veteraner sammenlignet med andre norske menn.

Risiko for selvmord blant veteranene kunne blant annet knyttes til mangel på sosial støtte, psykiske helseproblemer og ufrivillig hjemsendelse fra tjenesten.

$\mathrm{N}$ orge har bidratt til FN /N ATO -operasjoner i mer enn 50 år. De fleste FN / N ATO -soldater har et positivt utbytte av tjenesten, men tidligere forskning viser at belastninger og stress i løpet av tjenesten kan medføre økt risiko for psykiske helseproblemer $i$ tiden etterpå. $M$ ålet med denne studien var å kartlegge forekomsten av, og risikofaktorer for, selvmord blant norske FN /N AT O -veteraner. Studien inneholder en undersøkelse av dødsfall blant alle som hadde tjenestegjort i FN /N AT O -styrkene i perioden 1978-1995. U ndersøkelsen viste at samtidig som det var en betydelig lavere risiko for sykdomsdødsfall, var det en $40 \%$ høyere risiko for selvmord sammenlignet med andre norske menn av samme alder i samme tidsperiode. For å kartlegge risikofaktorer for selvmord ble det gjennomført en intervjuundersøkelse av nære pårørende til veteraner som var døde av selvmord. To sammenligningsgrupper ble brukt: 1) Intervjuer med nære pårørende til veteraner som var døde av ulykker, og 2) en spørreskjemaundersøkelse blant FN -veteraner. A lvorlige psykiske helseproblemer, det å bo al ene og det å nylig å ha opplevd brudd med partner var viktige risikofaktorer. Personer som ufrivillig var blitt hjemsendt fra FN / N AT O-tjenesten, syntes også å ha høyere selvmordsrisiko. Denne studien kunne derimot ikke vise noen direkte sammenheng mellom posttraumatiske reaksjoner og selvmord. 0 gså dødsulykkene ble undersøkt nærmere.

Resultatene tyder på at mange alkohol relaterte dødsulykker kan være knyttet til psykiske helseproblemer, selvdestruktivitet eller til en redusert interesse for, eller evne til, å ivareta egen sikkerhet. A vhandlingen gir forslag til selvmordsforebyggende tiltak for FN /N ATO veteraner.

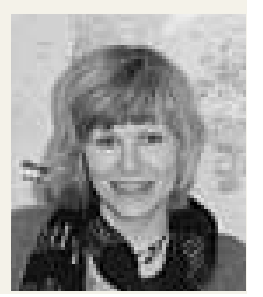

